\title{
Student Life in Canadian Universities: The Lessons of History ${ }^{1}$
}

\author{
PAUL AXELROD*
}

\begin{abstract}
This article explores the relationship between the history of the student experience and contemporary student life. It identifies enduring patterns in three areas: the social origins of students, student culture and activism, and the perceived academic quality of students. Reflecting their predominantly middle class backgrounds, university students have craved social status and feared the prospect of downward mobility, particularly in hard economic times. They have forged a student culture which serves to relieve academic tensions and strengthen their claim to social distinctiveness. Sexist outbursts by male students, past and present, speak to fundamental feelings of insecurity in the face of feminist movements. Political activism among a sizable minority of students, which predated the 1960s, now shows signs of re-emergence at a time when students sense that their long term goals may be frustrated. Finally, the professorial contention that students are academically less competent than ever has been heard before. A historical perspective, brought to this and other issues, should deepen understanding of the nature of student life.
\end{abstract}

\section{RÉSUMÉ}

Cet article étudie le rapport qui existe entre l'histoire vécue de l'étudiant et la nature de sa vie étudiante. L'auteur constate qu'il existe des comportements persistants dépendant de trois facteurs : l'origine sociale de l'étudiant, sa culture et son dynamisme, et enfin la façon dont il perçoit sa valeur en tant qu'étudiant. Les étudiants universitaires, en grande majorité originaires de classes moyennes, sont à la recherche d'un statut social prestigieux et craignent de tomber dans une classe inférieure à celle dont ils sont issus, surtout à une époque difficile du point de vue économique. Ils se forgent des valeurs dont le but est de les soulager des tensions liées aux études et de renforcer leurs prétentions de distinction sociale. Les éclats sexistes passés ou présents expriment le profond sentiment d'insécurité que certains étudiants éprouvent vis-à-vis des mouvements féministes. L'activisme politique, anciennement associé aux années soixante, semble renaître dans une 
minorité non négligeable d'étudiants du fait que ceux-ci sentent bien qu'ils risquent de ne pas parvenir à leurs fins à long terme. De plus, c'est un lieu commun, dans le corps professoral, d'affirmer que les étudiants sont de plus en plus médiocres. Si l'on étudie la question d' un point de vue historique, tant dans ce numéro que dans ceux qui vont suivre, on devrait être en mesure de mieux comprendre de quoi est faite la vie quotidienne des étudiants.

In assessing the state of historical writing on Canadian universities, I concluded in 1982 that the literature in general was analytically shallow, overly celebrationist, and still languishing on the margins of Canadian historiography. (Axelrod 1982). Even allowing for the arrogance of relative youth emanating from this evaluation, the verdict was judicious, if harsh, and not mine alone. (Reid 1984; Sheehan 1985; Berger 1986).

While it would be an exaggeration to declare that all has subsequently changed in the writing of university history, on balance, one can fairly conclude that the past decade has been kind to this literary genre. Books and articles on university life tend no longer to focus exclusively and uncritically on the feats and foibles of the "great men" who administered the institutions. Historians instead probe with greater depth and sophistication the intellectual and social milieux of higher learning in Canada and elsewhere. Faculty and students are the subject of increasing interest. Women are no longer ignored. The importance of universities to class relations, economic conditions, youth culture, and regional life has been discovered and explored. The institutional histories and biographies of exuniversity presidents, like that of Robert Falconer of the University of Toronto (by James Greenlee), are richer and analytically more subtle than once was the case (Greenlee 1988). In general, the historiography of higher education has been touched by and benefited from the impressive methodological and thematic developments in the writing of history itself. ${ }^{2}$

Should any of this matter to anyone outside the tiny community of educational historians in Canada? Recognizing that this journal's readership consists primarily of non-historians, and intent as I am on keeping its attention, I want to argue that what we now know about the past may well be important in helping us understand some contemporary aspects of university life.

My own research in recent years has focused on the experience of university students between the two world wars: who they were, why they enrolled, what they were taught, what social, cultural and political outlets they chose, and what happened to them after they left university. On the basis of this work and that of historians who have examined other periods, I am confident that we have clearer insights into the nature of the student experience. Furthermore, it should now be possible to set to rest a number of enduring educational myths about student life and the university itself - some of which have affected, and unfortunately afflicted, public opinion and educational policy. 
In this article, I want to highlight some of these conclusions derived from the historical record with respect to the following issues: the social origins of students, the nature of student culture and activism, and the academic quality and performance of students.

It is often claimed and is widely believed that university students are and have always been an elite group: privileged members of the bourgeois class, for whom post-secondary education offers a genteel preparation for an entitled life in society's upper echelons. I largely shared this perspective before I began reading some new research on this subject and conducting some of my own. It is a view which, in light of the evidence, merits some serious reconsideration and qualification.

On the basis of work by historians David Allmendinger and Colin Burke, we now know that American universities and colleges in the nineteenth century contained a far wider social mix of students than was previously believed. Between 1800 and 1860 a significant and growing percentage of New England students came from poor families. They confronted the reality of declining rural life by seeking new opportunities as middle class professionals in the emerging industrial world (Almendinger 1975; Burke 1982).

A study of Queen's University's constituency in the 1890s shows that while the students were relatively more privileged than the population as a whole, their social origins (with respect to their fathers' occupations) were more modest and diverse than we have generally realized (Gaffield et al. 1989). My own research on the 1930s confirms this perception. I found that the majority of students were middle class, not upper class, that their economic status ranged from the exceedingly modest to the very comfortable, and that many had severe economic problems. For example, one third of the 1700 students at the University of Saskatchewan could not afford to pay their tuition fees in 1934, hardly an indication of lofty social position. Over 60 per cent of Canadian students did come from professional, business, or managerial backgrounds, which, of course, made them more advantaged than the general Canadian population, but many of the small merchants and professionals such as clergymen and teachers, earned meagre incomes, barely above the average industrial wage of the Canadian workforce. During the Depression, it was possible, if not the common experience of students, to be both middle class and poor. A little more than 20 percent of the students came from families whose fathers were white collar, skilled or unskilled workers people, in other words, of fairly humble means (Axelrod 1990).

Elitism was far from absent on the Canadian campus; extraordinarily wealthy and privileged students could be found, particularly among exclusive circles at McGill and Toronto, but this did not represent the experience of the typical Canadian student.

Important changes in the economy and social structure have taken place since World War II, but these historical patterns with respect to the social origins of Canadian students still appear to prevail. While up-to-date research is required on this subject, I believe it is safe to conclude that university students come from more 
privileged backgrounds than the population as a whole - the children of working class and poor families have yet to be fully represented among the student population - but by no means are today's students uniformly or even typically wealthy (Porter 1965; Pike 1981; Axelrod 1982). ${ }^{3}$

Students generally, then, have middle-class origins and middle-class goals. In David O. Levine's words, theirs is a "culture of aspiration" not of presumption or ostentation (Levine 1986). They have been and remain preoccupied with the quest for status. They seek to improve their social positions by doing better (occupationally) than their parents, or maintain their social status by doing as well as their parents. A source of deep anxiety is the fear that they will lose social status by doing worse than their parents, a particular concern, I would submit, among the children of well-educated, class-conscious, baby boom Canadians.

Insecurity and fear of failure are, as historians tell us, an enduring part of middle-class culture, and certainly one of the main causes of student stress (Bledstein 1976; Ryan 1981; Ehrenreich 1989; Neumann et al. 1990). Thus once we understand that undergraduate students are less a pretentious elite brimming with confidence about their fate and future than they are a community of struggling, often diffident individuals of middling means and grand expectations, we can gain a clearer insight into the psychology and structure of student culture and student life.

These feelings of anxiety about the future are especially severe in difficult economic times, like the Depression of the 1930s, and the periodic recessions of the $1970 \mathrm{~s}$ and $80 \mathrm{~s}$. In the former era, students responded to the reality of diminished employment prospects in two ways: by working very hard in their academic studies, and by participating fully in campus social life. They hoped that their degrees would enhance their employability if not immediately, then at some point in the future when conditions improved. In the meantime they relished the social whirl, forging enduring friendships, joining clubs and fraternities, dancing their hearts out (over the frequent objection of stodgy administrators), and escaping, if only temporarily, from the cruel economic and social realities of Depression life (Axelrod 1990: chap. 5).

Are there echoes of this today? For at least the past decade in a chronically unstable economy, students have been unable to assume that a university degree would lead automatically to a secure, prestigious career. As enrolments and participation rates in higher education have risen, the negotiating value of the B.A. has diminished in the marketplace. The competition for entry into professional programs has become especially severe. There is, consequently, an intensity in the classroom, a preoccupation with grades, a greater desire to consume than question knowledge, a more evident concern with the educational payoff rather than with the educational process (Moffat 1989: 271-309, Johnston et al. 1986: 113, Mallick 1986, Haynes 1984). This rather conservative academic environment is paralleled and reinforced by the return to respectability in the $1980 \mathrm{~s}$ of the acquisitive capitalist ethic in the western, and perhaps now also, the eastern world. 
In a time of economic uncertainty, as in the past, a potent combination of ambition and insecurity fuel student life (Lefkowitz-Horowitz 1987: chaps 11-12).

In this strained atmosphere students crave social release. Given the massive size of the commuter population, proportionately fewer students today find these recreational outlets on campus than was the case earlier in the century when universities were more intimate places. Still, there are some interesting extracurricular trends of late that speak to the stresses of student life.

First, they consume large amounts of alcohol. In the past several years, alcohol-related student deaths occurred at Ryerson, Wilfrid Laurier and Guelph universities. Predictably sensationalized by the media, these tragedies should not be dismissed simply as orientation exercises gone awry. A 1989 survey of students at four Ontario universities found that boozing is a year-round activity. Each week the average student downs 12 alcoholic drinks. But 18 per cent consume 15 to 28 drinks, and 12 per cent more than 28 drinks (Glicksman et al. 1989: 19, Johnston et al. 1986: 124-5, Moffat 1989: 123-4, Lefkowitz-Horowitz 1987: 277).

There is nothing new about the close relationship between students and the brewing industry, though its product has probably never been as accessible on campus as it is today. (Over one million bottles of beer were sold at Guelph University in 1987, making it the beer industry's fourth largest Ontario account). A lucrative student business, lovingly cultivated by the big companies, the college pub is a popular social venue both for students seeking simply to relax and those trying desperately to escape.

Secondly, we are witnessing the revival of fraternity life on Canadian campuses. In an earlier incarnation, fraternities spread throughout the United States in the nineteenth century where they gradually set new standards for social achievement in an increasingly secular society. They developed codes of behaviour that students, aspiring to success in the business and professional worlds, felt obliged to follow. Infused with class bias, they placed great emphasis on a student' social background, race and religion, athletic prowess, appearance, and ability to mix smoothly in the proper circles. While they never achieved the same degree of importance in Canada as in the U.S., they did become popular throughout this country in the 1920s and 1930s, a time when Canadian students were increasingly influenced by trends and fashions in American popular culture. Fraternities were tolerated by Canadian university authorities because they could not really prevent them from functioning unoffically, and because they aided universities by providing male students with off-campus housing that was otherwise unavailable (Fass 1977: 142-57, Axelrod 1990: 105-8).

Fraternities were pushed from the mainstream of campus life during the 1960s by a student culture which generally opposed elitism in favour of egalitarianism, and until recently fraternity enthusiasts have lived a kind of quiet, underground existence.

They have resurfaced in the last few years for a number of reasons: first, in the anonymous mass-a-versity, many students are searching for associational bonds 
that offer them individual identities within smaller social networks. Second, they seek to provide their members with a source of distinction and exclusiveness in an era when the open pursuit of status is once again respectable; and third, they reward male bonding and machismo-like rites of passage at a time when many undergraduate men feel compelled to reassert traditional sex roles. (LefkowitzHorowitz 1987: 273-9, Teahen 1986; Crawford 1987; Axelrod 1988; Semenak 1988; Walden 1989; English 1986).

The open hostility of some (though by no means all) university men to symbols of feminism is itself a sign of both conservatism and insecurity within male student culture. The misogynist outbursts at Queen's University in response to a rape-awareness educational campaign in the fall of 1989, the increasing incidence of panty raids, the verbal attacks on women's studies programs and the women who enrol and teach in them, the antagonism of some male students towards their women instructors, and the frequency of sexual assaults on women (on and off campus) point to a disquieting and even unexpected mood within universities (DeKeseredy 1989; Dickie 1990; Cernetig 1990; Kirkey et al. 1989; LefkowitzHorowitz 1987: 277-8).

But the bellicose response of some groups of men to the recent wave of feminism is reminiscent of their reactions in the late nineteenth century to the initial admission of women to Canadian universities. In a form of territorial reassertion, men created campus clubs that excluded women and attacked with considerable vitriol the principle of co-education. Universities and professional associations shared this sentiment to the extent that they either barred or imposed quotas on the admission of women (and racial and ethnic minorities) to elite "male" professions. ${ }^{4}$ As historians such as Lee Stewart have shown, throughout the twentieth century, university women were forced to fight vigilantly for mere respectability, let alone equality of treatment on campus. The successes they achieved were usually qualified ones (Stewart 1990; Gillet 1981; McKillop 1989; Kiefer et al. 1989; Prentice 1989).

University men thus felt threatened by campaigns for gender equality in the past. Today, because men must compete with women for the same professional opportunities, the stakes may be even higher. Males, therefore, are on the verge of losing the extra margin of advantage that gender once provided them in the labour market. Most are likely adjusting to this reality, but some of the most insecure and desperate are having considerable difficulty. None have struck out with the psychotic violence of Marc Lépine, who murdered 14 women and killed himself at Ecole Polytechnique in Montreal in December 1989, but the less bloody episodes of sexist animus cannot be overlooked and should not be minimized. Insisting on power over women is the desperate clarion call of men who feel powerless in other areas of their lives. The more uncertain they are about their own prospects, the more responsive some men are to the anti-feminist currents now rippling across the land. History shows us that universities were not immune to similar social pressures in the past, and they are not immune now.

The student mood on campus may now be relatively conservative, but student activism is not necessarily dead. In any event, the historical record indicates that 
once decreased, it never stays dead for long. The 1960s, against which so much is measured in the popular and academic culture, certainly witnessed an unprecedented degree of what was euphemistically called "student unrest." Those of us responsible for it were quite certain that we were pioneers, that we had invented the phenomenon of the student movement. And in the midst of the turmoil, university administrators longed for a return to an era when students were supposedly more passive and polite.

Ex-radicals and contemporary university authorities alike should be informed that campus activism was not born in the 1960s. It reached back to medieval Europe when universities were first established, played an active part in the revolutionary movements of Europe and America in the eighteenth century, and continued to erupt frequently, if unpredictably, in the United States and Canada throughout the nineteenth century (Cobban 1971; Novak 1987; LefkowtizHorowitz 1987: chap. 2; de Conde 1971; Axelrod 1990: 17). During the 1930s Canadian, American, and European students all participated in organized anti-war demonstrations. Peace marches, vigils and petition campaigns, which historical myth now associates almost exclusively with the 1960 s, all occurred in an earlier age. It would be stretching the evidence to suggest that student activism has been the norm, not the exception, in the long history of student life, but university officials today are naive if they believe that that "problem" is forever behind them (Simon 1987; Eagan 1981; Axelrod 1989).

Even in the individualistic, materialistic culture of the past decade - caricatured by the yuppie youth slogan, "Don't trust anyone under $\$ 30,000$ " - there have been episodes of collective protest that recall the mood of the 60 s. Some students, identifying strongly with the women's movement, have participated in the development of women's studies programs, and university policies designed to confront sexual harassment. In 1985-86, students at universities across the continent organized some intensive and successful campaigns demanding that their institutions divest themselves of holdings in companies conducting business in South Africa (Altbach et al. 1990).

More recently, students throughout the country, most notably in Quebec and British Columbia, have held demonstrations and sit-ins to protest tuition fee increases. In March 1990, 200 students in Montreal alone were arrested in confrontations with the police (Globe and Mail 1990). In the same month at my own university, York, several hundred students interrupted a Board of Governors meeting, demanded that the university withdraw a new, more expensive, residence meal plan, and won.

Given their heightened consciousness as consumers, students want to reduce the obstacles - financial and otherwise - that interfere with their pursuit of middle class and professional status. Vaguely aware of historical precedents linked to the legendary $60 \mathrm{~s}$ and particularly to the student experience, they may be willing to use unconventional tactics to achieve these conventional ends.

Thus university authorities and faculty should not take student passivity for granted, even in conservative times. The student-administration relationship is always dynamic and potentially explosive. Today's students may not be inspired 
by deep ideological commitments, but they can be driven to activism nonetheless. When they are treated in arbitrary and patronizing ways, when they are frustrated academically or economically by gigantic classes or unaffordable fees, and if they sense, finally, that their long-term goals are unattainable, then, as in previous eras, they may well turn to protest and resistance.

However distinct they are at first glance, today's students thus share with those in other eras certain values and sensibilities linked to their social origins and aspirations. They share something else: the contempt of some frustrated professors who are convinced that the current generation of students is the most shallow and incompetent in history.

The arguments of polemics such as Allan Bloom's, The Closing of the American Mind (1987), and The Great Brain Robbery: Canada's Universities on the Road to Ruin (1984) by Canadian historians David Bercuson, Robert Bothwell and J.L. Granatstein are by now familiar. The authors contend that universities have been in a continuous state of decline since at least the Second World War, that they are now too easily accessible to mediocre, frequently illiterate (or at best non-literate) students, and that higher education, to its detriment, has embraced through its curriculum and hiring policies such "trendy" causes as feminism and minority rights. Classical liberal education has thus been diluted by a potent combination of collapsing academic standards and political expediency. "Canadians are being robbed," exclaimed Bercuson et al., "so let something be done quickly!" (1984: 1, 160).

These books, especially Bloom's best seller, created quite a sensation. By chastizing public schooling for its obvious imperfections, they spoke to a general desire among educators and parents for improvements in the quality of teaching, learning and scholarship. That the authors' sweeping claims, particularly about student life, were based so extensively on impressionistic and anecdotal evidence, struck a number of academics, including me, as ironic in light of their comments about the state of university scholarship (CAUT Bulletin 1984).

What is most striking about this conservative and "nostalgic" approach to university life is its ahistorical hankering for a mythical golden age of higher education. (Axelrod 1986). The authors of The Great Brain Robbery hold up the 1920 s and 30 s as an era "when universities and colleges existed primarily as liberal arts institutions training young men and women how to think." (Bercuson et al. 1984: 67). But Hamilton Fyfe, the principal of Queen's in the 1930s, declared that education in Ontario was "only a rumor," and that his own institution's undergraduate program "would not elevate a cow." (Gibson 1983: 109-10). In 1936, Dalhousie's president, Carleton Stanley, complained that "in no generation have there been such stunning distractions from study as movies, comic strips, jazz music and other alleged amusements." (Stanley 1936). Compare this with Allan Bloom's description of contemporary rock music as a "nonstop, commercially prepackaged masturbational fantasy" to which adolescents and university students are hopelessly addicted. (Bloom 1987: 75). However entertaining, such caricatures (past and present) shed little light on the nature of youth culture or the quality of students. 
Though it is certainly important, the issue of student performance is exceedingly difficult to probe meaningfully from a historical perspective. My investigation of the 1930s found that for every professor who dismissed students as generally incompetent, there was another who praised their collective tenacity and intelligence. (Axelrod 1990: 48-9). The problem is complex. Do high failure rates testify to the toughness of standards or the abysmal quality of classroom work? Do improving grades indicate advancing levels of scholarship or runaway grade inflation? Given how standards and expectations vary from university to university today, is it even possible to compare a B in 1940 with a B in 1990? Reviewing actual written work is perhaps a more reliable method of evaluating student performance in different periods. Such materials, however, are usually not available, and even where they are, drawing general conclusions from scattered or selected student papers, the quality of which would undoubtedly be mixed, is risky.

Many academics today point to diminishing literacy levels as a sign of the relentless deterioration of student work. All of us, of course, have encountered students who should not be in university because they cannot write a coherent paragraph. But there are three things to be said about this. First, this is not a new phenomenon. Educators have been struggling with this problem since the origin of schooling. Second, when academics suffer the abominable student, they sometimes lose all perspective of generalizing wildly from these individual experiences, a methodological approach for which they would surely penalize students writing social science essays. Third, when professors like Allan Bloom in the 1980s, Hilda Neatby in the 1950s (Neatby 1953), or Hamilton Fyfe in the 1930s denounce students, they are usually objecting as much to the current state of popular culture or of western civilization itself, as to that of the contemporary university. They demand - as if this were ever the case or even possible - that the university insulate itself from cultural and social forces swirling about the institution. More than anything, these treatises, however passionately and provocatively written, reflect the authors' own discomfort with social change.

At this stage, I can do no more than offer these terribly modest conclusions on the question of the history of student quality. University youth have never been uniformly brilliant or totally incompetent - the majority have fallen somewhere in the middle. Educators and historians should certainly be encouraged to explore more fully and creatively the issue of student performance. But idiosyncratic or ideologically-laden polemics contribute precious little to this task.

\section{CONCLUSION}

By offering context and perspective, "new wave" historiography can help sharpen our understanding of contemporary student life. The record suggests that while relatively advantaged socially, students have been less presumptuous, both materially and attitudinally, than popular legend implies. Their preoccupation with the pursuit of social status in hard times has several potential consequences: it can induce them to concentrate on achieving marketable grades; or to relieve the 
academic pressure by participating in a raucous and sometimes (self-) destructive social life; or to lash out at administrators or fellow students who are perceived to threaten one's own prospects for advancement. History also shows that an awareness of their comparative class privilege, and the unique opportunity that university offers for intellectual discovery, can inspire students to think critically about the world around them and to participate in campaigns for educational and social change. Finally, history suggests that we can learn more about university life by listening to students and by taking them seriously, than we can from those aging observers who romanticize, denounce, dismiss, or in other ways distort the student experience.

\section{NOTES}

1 Adapted from a paper presented to the conference of the Canadian Society for the Study of Higher Education, Victoria, June 3, 1990.

2 For a discussion of the recent literature and a comprehensive list of Canadian sources, see Axelrod and Reid 1989.

3 By demonstrating the over-representation in Canadian universities of children from business and professional backgrounds, John Porter's classic work, The Verical Mosaic confirmed the role of higher education in reproducing a social and economic elite. However, the same statistics showed that the parents of some 50 per cent of students attending universities and colleges in 1956 were clerical and sales workers, skilled and semi-skilled workers, farmers, and laborers (184). Statistics for 1974-5 show that 41 per cent of undergraduate students in Canada had fathers who attained some post-secondary education (compared to 24 per cent of the male population, age 45-64). This left 59 per cent whose parents had no more than a secondary education (compared to 77 per cent of the total male population). (Pike 1981: 32). See also Axelrod 1982: 152-3, 198).

4 Beginning in the 1920s, universities also restricted access to Jews and other ethnic and racial minorities, a practice that student groups emulated. For a discussion of such discriminatory practices, see Axelrod (1990: 32-8).

\section{REFERENCES}

Allmendinger, David. (1975). Paupers and Scholars: The Transformation of Student Life in Nineteenth Century New England. New York: St. Martin's Press.

Altbach, Philip G. and Robert C. Cohen. (1990). American Student Activism: The Post-Sixties Transformation. Journal of Higher Education, 6l(1): 33-49.

Axelrod, Paul. (1988). Fraternal Fun and Games Nothing to Laugh About. Globe and Mail, 12 January, p. 6.

Axelrod, Paul. (1982). Historical Writing and Canadian Universities: the State of the Art. Queen's Quarterly, 89(1): 137-44.

Axelrod, Paul. (1990). Making a Middle Class: Student Life in English Canada during the 1930s. Montreal: McGill-Queen's University Press.

Axelrod, Paul. (1986). Romancing the Past: Nostalgic Conservatism, The Great Brain Robbery, and the History of Education, paper delivered to the Canadian History of Education Association, Halifax. I develop the theme of education as historical romance in this paper.

Axelrod, Paul. (1982). Scholars and Dollars: Politics, Economics and the Universities of Ontario: 1945-1980 Toronto: University of Toronto Press.

Axelrod, Paul. The Student Movement of the 1930s, in Axelrod and Reid, eds., Youth, University, and Canadian Society, pp. 216-46. 
Axelrod, Paul and John G. Reid, eds. (1989). Youth, University, and Canadian Society: Essays in the Social History of Higher Education. Montreal: McGill-Queen's University Press.

Bercuson, David J., Robert Bothwell, J.L. Granatstein. (1984). The Great Brain Robbery: Canada's Universities on the Road to Ruin. Toronto: McLelland and Stewart, pp. 1, 160.

Berger, Carl. (1986). The Writing of Canadian History. Toronto: University of Toronto Press, 2nd edition.

Bledstein, Burton. (1976). The Culture of Professionalism: The Middle Class and the Development of Higher Education in America. New York: Norton.

Bloom, Allan. (1987). The Closing of the American Mind. New York: Simon and Schuster.

Burke, Colin. (1982). American Collegiate Populations: A Test of the Traditional View. New York: New York University Press.

CAUT Bulletin. (1984). Various reviews of The Great Brain Robbery, 31(8).

Cernetig, Miro. (1990). University Fights Outbreak of Sexism Virus. Toronto Globe and Mail, 25 April, p. 1 .

Cobban, Alan B. (1971). Medieval Student Power. Past and Present, 53: 28-66.

Crawford, Trish. (1987). Tuxedo-clad 'Frats' Back in Fashion, Toronto Star, 27 December, 1.

de Conde, ed., Alexander. (1971). Student Activism: Town and Gown in Historical Perspective. New York: Charles Scribner's Sons.

DeKeseredy, Walter. (1989). Dating Relationships: An Exploratory Study, Atlantis, 14(2): 54-62.

Dickie, Alison. (1990). Sexism and Destiny at Queen's. This Magazine, 23(7): 24-6.

Eagan, Eileen. (1981). Class, Culture and the Classroom: The Student Peace Movement of the 1930s. Philadelphia: Temple University Press.

English, Kathy. (1986). Frosh Grin and Bear Rites of September, Toronto Star, 7 September.

Fass, Paula. (1977). The Damned and the Beautiful: American Youth in the 1920s. New York: Oxford University Press.

Gaffield, Chad, Lynne Marks, and Susan Laskin. (1989). Student Populations and Graduate Careers: Queen's University 1895-1900, in Axelrod and Reid, Youth, University, and Canadian Society, 3-25.

Gibson, Frederick W. (1983). To Serve and Yet Be Free: Queen's University. Montreal: McGillQueen's University Press 1983.

Gillet, Margaret. (1981). We Walked Very Warily: A History of Women at McGill. Montreal: Eden Press Women's Publications.

Glicksman, Louis et al. (1989). The Drinking, Drug Use, and Lifestyle Patterns of Ontario University Students. London, Ont.: Addiction Research Foundation.

Globe and Mail. (1990). March 31, 1990, p. A-1.

Greenlee, James G. (1988). Robert Falconer: A Biography. Toronto: University of Toronto Press.

Harris, John. (1989). Concern Grows over Campus-Alcohol Links. Globe and Mail, 10 February, A-9.

Haynes, Dave. (1984). Exam Stress. Winnipeg Free Press, 3 April.

Kiefer, Nancy and Ruth Roach Pierson. The War Effort and Women Students at the University of Toronto, 1939-45, in Axelrod and Reid, Youth, University, and Canadian Society, pp. 161-86.

Kirkey, Sharon, and John Ibbitson. (1989). Sexism Still Rife on Canadian Campuses. Calgary Herald, 10 December, p. C2.

Johnston, Charles M. and John C. Weaver et al. (1986). Student Days: An Illustrated History of Student Life at McMaster University from the 1890s to the 1980s. Hamilton: McMaster University Alumni Association.

Lefkowitz Horowitz, Helen (1987). Campus Life: Undergraduate Cultures from the End of the Eighteenth Century to the Present. New York: Alfred A. Knopf.

Levine, David O. (1986). The American College and the Culture of Aspiration, 1915-1940 Ithaca: Cornell University Press 1986. 
Mallick, Heather. (1986). University Stressful, Suicide Expert Says, Toronto Globe and Mail, 22 April, M-1.

McKillop, Brian (1989). Marchings as to War: Elements of Ontario Undergraduate Culture, 1880-1914, in Axelrod and Reid, Youth, University and Canadian Society, pp. 75-93.

Moffat, Michael. (1989). Coming of Age in New Jersey: College and American Culture. New Brunswick, N.J.: Rutgers University Press.

Neatby, Hilda. (1953). So Little for the Mind. Toronto: Clarke, Irwin.

Neumann, Yoram, Edith Finlay-Neumann, and Arie Reichel. (1990). Determinants and Consequences of Students' Burnout in Universities. Journal of Higher Education, 6I(1): 20-31.

Novak, Steven. (1987). The Rites of Youth: American Colleges and Student Revolt, 1798-1815. Cambridge, Mass.: Harvard University Press.

Pike, Robert. (1981). Contemporary Directions and Issues in Education: A Sociologist's Views of the Last Twenty Years, in J. Donald Wilson (ed.), Canadian Education in the 1980s. Calgary: Detselig.

Porter, John. (1965). The Verical Mosaic. Toronto: University of Toronto Press.

Prentice, Alison. (1989). Scholarly Passion: Two Persons Who Caught It. Historical Studies in Education, $I(1)$ : 7-27.

Reid, John G. (1984). Some Recent Histories of Canadian Universities. American Review of Canadian Studies, 14(3): 369-73.

Ryan, Mary. (1981). Cradle of the Middle Class: the Family in Oenida County, New York, 1790-1865. Cambridge: Cambridge University Press, esp. chap. 4.

Semenak, Susan. (1988). Nightmare in McGill Ghetto: Residents Blame Frats. Montreal Gazette, 15 October, p. A-5.

Sheehan, Nancy M. (1985). History of Higher Education in Canada. Canadian Journal of Higher Education 15, no. 1: 25-38.

Simon, Brian. (1987). The Student Movement in England and Wales during the 1930s. History of Education, 13(3): 189-203.

Stanley, Carleton. (1936). School and College. Speech to the meeting of the National Conference of Canadian Universities, June, President's Papers, Dalhousie University Archives.

Stewart, Lee. (1990). "It's Up to You": Women at UBC in the Early Years. Vancouver: University of British Columbia Press for the UBC Academic Women's Association.

Teahen, Kelley. (1986). Sororities Offer Students Friendship, Responsibility. Winnipeg Free Press, 10 February, p. 23.

Toronto Star. (1989). 18 Per Cent Drink 'Heavily' in University, Study Shows, 15 February, p. A-1. Walden, Keith. (1989). Hazes, Hustles, Scraps and Stunts: Initiations at the University of Toronto, 1880-1925, in Axelrod and Reid, eds., Youth, University, and Canadian Society, pp. 94-121. 